\title{
Upaya Peningkatan Pengetahuan Tentang Dampak Negatif Penggunaan Gadget Dan Deteksi Dini Gangguan Sensomotorik Serta Perubahan Postural Pada Anak
}

\author{
Titin Kartiyani ${ }^{1}$, Dhiah Dwi Kusumawati ${ }^{2}$, Tri Budiarti ${ }^{3}$ \\ ${ }^{1}$ Prodi D3 Fisioterapi, ${ }^{2,3}$ Prodi D3 Kebidanan \\ STIKES Al Irsyad Al Islamiyyah Cilacap, Jalan Cerme 24 Sidanegara Cilacap \\ Email Korespondensi: tien.fisio@gmail.com
}

\begin{abstract}
Abstrak
Anak usia dini saat ini sudah pandai menggunakan gadget. Penggunaan Smartphone (gadget) dikalangan anak - anak semakin memprihatinkan dan tentu memiliki dampak negatif terhadap tumbuh kembang. Dampak negatif penggunaan gadget yang berlebihan pada anak antara lain membatasi gerak fisik anak sehingga tumbuh kembang fisik anak menjadi terlambat. Selain itu, penggunaan gadget yang berlebihan pada anak akan menyebabkan obesitas sehingga anak mengalami gangguan postural. Berdasarkan hal itu, tim pengabdian masyarakat ingin melakukan kegiatan pengabdian untuk meningkatkan pengetahuan dan mendeteksi secara dini ganguan sensomotorik dan postural sebagai upaya pencegahan efek negatif penggunaan smartphone (gadget) pada anak PAUD di wilayah Desa Slarang. Tim pengabdian menggunakan dua metode dalam hal ini. Metode pertama dengan melakukan screening dengan DDST kemudian dilanjutkan metode berikutnya dengan memberikan penyuluhan. Kegiatan pengabdian diikuti oleh 16 peserta orang tua dan balitanya masing-masing. Pemeriksaan screening terhadap 16 balita menunjukkan tidak adanya gangguan sensomotorik dan postural. Pre tes sebelum penyuluhan memiliki nilai rata-rata 5,7 dan naik pada saat setelah penyuluhan dilakukan dengan nilai post tes rata-rata 8,1 . Kesimpulannya tidak adanya balita yang mengalami gangguan sensomotorik dan postural, selain itu pada orang tua terjadi peningkatan pengetahuan.
\end{abstract}

Kata Kunci : gadget, postural, anak

\begin{abstract}
Early childhood are now good at using gadgets. The use of gadgets among children is increasingly apprehensive and certainly has a negative impact on growth and development. The negative impact of excessive use of gadgets on children, among others, limits the child's physical movement so that the child's physical development becomes too late. In addition, excessive use of gadgets in children will cause obesity so that children experience postural disorders. Based on that, the community service team wants to carry out community service activities to increase knowledge and detect sensory and postural disorders early as an effort to prevent the negative effects of gadgets use on PAUD children in the Slarang area. The dedication team uses two methods in this regard. The first method is by screening with DDST then followed by the next method by providing counseling. The dedication activity was attended by 16 parent participants and their toddlers respectively. Screening examinations for 16 children showed no sensomotor and postural disorders. Pretest before counseling has an average value of 5.7 and rises at the time after counseling is carried out post-test with an average value of 8.1. The conclusion is that there are no toddlers who experience sensomotor and postural disorders, but in parents there is an increase in knowledge.
\end{abstract}

Key words: Gadget, postural, child 


\section{PENDAHULUAN}

Hampir tiap individu mulai dari anak-anak hingga orang tua kini memiliki handphone/smartphone atau yang saat ini dikenal sebagai gadget. Kini kebutuhan akan komunikasi dan informasi menjadi hal yang paling penting bagi semua kalangan ditambah mudahnya mengakses berbagai macam fitur yang ditawarkan dan berbagai provider pendukung. Gadget adalah perangkat elektronik kecil yang memiliki fungsi khusus. Salah satu yang membedakan gadget dengan perangkat elektronik lain adalah unsur kebaruan yang menyajikan teknologi baru yang membuat hidup manusia menjadi lebih praktis.

Anak usia dini saat ini sudah pandai menggunakan gadget. Novi (2015:154) menyatakan kebiasaan anak yang menghabiskan waktunya untuk bermain game akan sangat berpengaruh pada kejiwaan. Penggunaan gadget pada anak usia dini biasanya untuk bermain game dan menonton animasi atau kartun anak-anak. Selain itu menurut Sari dan Mitsalia (2016) melaporkan bahwa rata-rata anak menggunakan gadget untuk main game dari pada menggunakan untuk hal lain.

Penggunaan gadget dikalangan anak-anak semakin memprihatinkan dan tentu memiliki dampak negatif terhadap tumbuh kembang. Terlihat jelas anak-anak lebih cepat beradaptasi dengan teknologi yang ada. Sehingga anak-anak sering terlena dengan kecanggihan gadget dengan fitur-fitur yang tersedia di dalamnya. Anak-anak yang sering menggunakan gadget seringkali lupa dengan lingkungannya. Mereka lebih memilih bermain gadget dari pada bermain bersama teman-teman dilingkungannya. Sehingga interaksi sosial antara anak dengan masyarakat, lingkungan sekitar berkurang bahkan semakin luntur. (Ismanto and Onibala, 2015). Penggunaan gadget yang berlebihan juga dapat mengakibatkan resiko obesitas. Obesitas akan berdampak pada postural anak karena penggunaan gadget dalam posisi statis yang lama akan meningkatkan resiko adanya perubahan postural pada anak.

\section{MASALAH}

Permasalahan saat ini penggunaan smartphone (gadget) pada anak selain memiliki dampak positif juga ada dampak negatif jika penggunaannya melebihi batas normal yaitu 3-8 jam sehari. Tidak hanya dampak negatif terhadap mata dan 
perilaku namun juga berpotensi mempengaruhi perubahan postur tubuh karena adanya penggunaan smartphone dalam posisi statis yang terlalu lama. Orang tua membiarkan begitu saja ketika anak memainkan gadget dengan alasan yang penting anak diam dan tenang. Berdasarkan permasalahan tersebut maka pengabdian dilakukan dengan tujuan untuk mengetahui adanya gangguan sensomotorik dan postural anak serta peningkatan pengetahuan orang tua terhadap dampak negatif penggunaan gadget.

\section{METODE}

Berdasarkan identifikasi masalah yang muncul maka kami memberikan solusi untuk mengatasi hal tersebut melalui beberapa kegiatan yaitu :

1) Pemeriksaan deteksi dini gangguan sensomotorik dan perubahan postural

Kegiatan ini dilakukan dengan pemeriksaan menggunakan formulir pemeriksaan DDST Denver II yang dilakukan oleh tim Pengabdian Masyarakat Stikes Al-Irsyad Al-Islamiyyah Cilacap. Pemeriksaan dilakukan langsung terhadap balita yang datang dengan didampingi orang tuanya. Alat dan bahan yang dibutuhkan untuk pemeriksaan berupa formulir DDST, Penggaris, dan alat tulis. Pemeriksaan DDST ini untuk mengetahui adakah gangguan sensomotorik akibat penggunaan smartphone dan pemeriksaan postural untuk mengetahui adakah gangguan pada postur anak yang menggunakan smartphone.

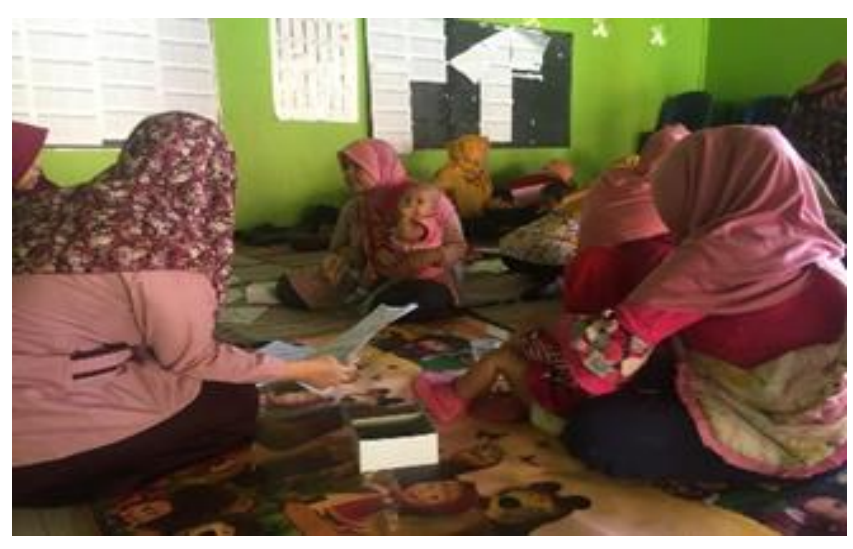

Gambar 1. Pemeriksaan/screening dengan DDST

2) Kegiatan Penyuluhan atau pendidikan kesehatan tentang dampak negatif penggunaan gadget

Kegiatan penyuluhan dilakukan oleh tim pengabdian kepada orang tua anak

PAUD di Desa Slarang Kecamatan Kesugihan Kabupaten Cilacap untuk 
meningkatkan pengetahuan orang tua tentang dampak negatif penggunaan gadget pada anak. Selain itu dalam penyuluhan ini para orang tua diberikan pendidikan kesehatan tentang berapa lama anak boleh bermain smartphone (gadget), bagaimana jarak yang baik dalam penggunaan smartphone (gadget) dan bagaimana cara mencegah agar anak tidak mengalami gangguan postural akibat penggunaan smartphone yang terlalu lama. Penyuluhan ini juga dilanjutkan dengan kegiatan diskusi. Sebelum dilakukan penyuluhan maka terlebih dahulu dilakukan pre test dengan pembagian kuesioner yang harus diisi oleh orang tua balita. Kuesioner ini diberikan sebagai langkah awal untuk mengetahui pengetahuan orang tua tentang dampak negatif penggunaan gadget serta untuk mengetahui berapa lama penggunaan gadget atau smartphone pada anak dan digunakan untuk apa saja serta adakah pengawasan saat anak bermain gadget. Kegiatan penyuluhan dan diskusi dilakukan sebanyak satu kali. Media yang digunakan dalam kegiatan penyuluhan adalah computer, LCD dan materi.

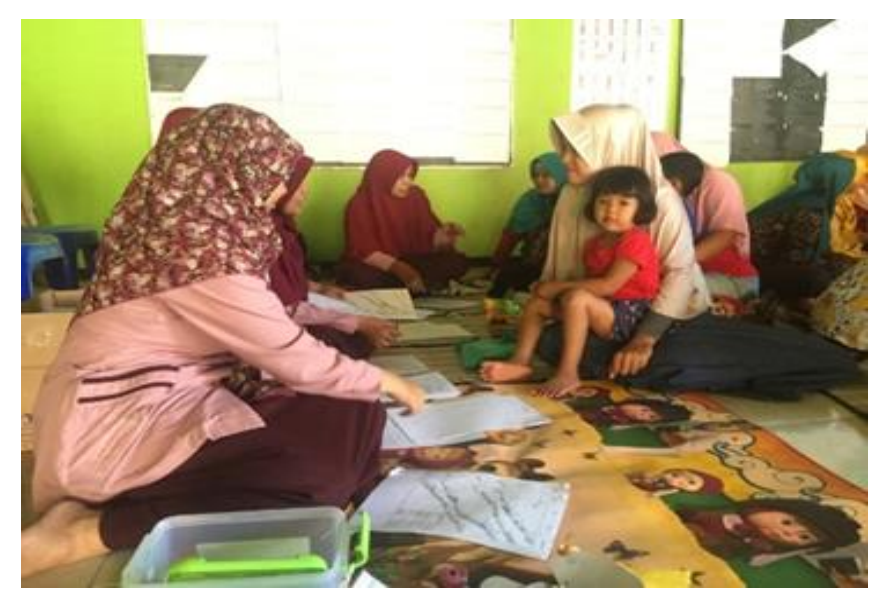

Gambar 2. Pre test dan post tes

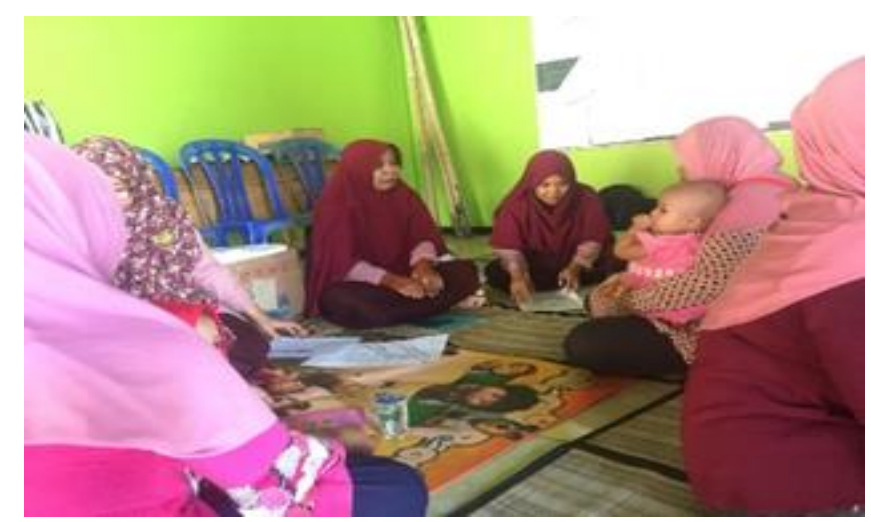

Gambar 3. Kegiatan Penyuluhan pada Orang tua 


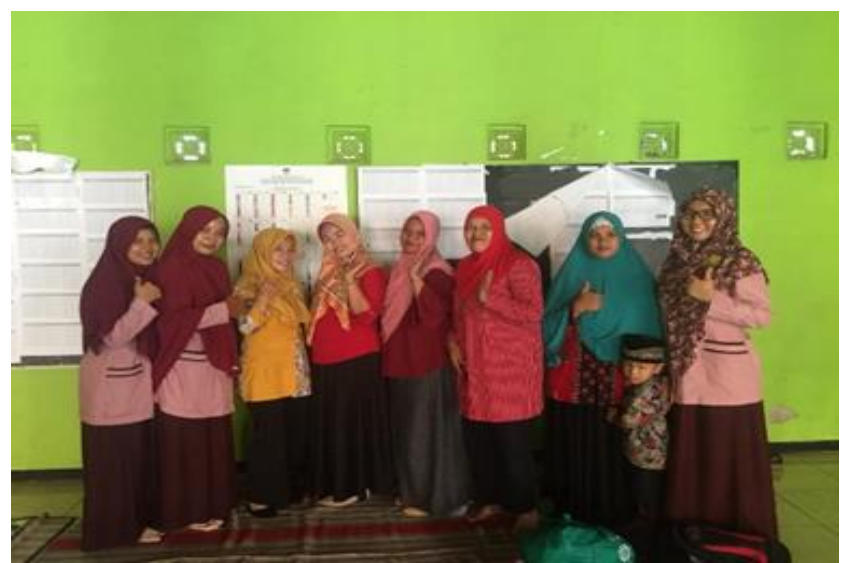

Gambar 4. Kegiatan penutupan bersama para kader dan orang tua

\section{HASIL DAN PEMBAHASAN}

1) Hasil

Pengabdian Kepada Masyarakat dengan judul Upaya Peningkatan Pengetahuan Tentang Dampak Negatif Penggunaan Gadget Dan Deteksi Dini Gangguan Sensomotorik Serta Perubahan Postural Pada Anak telah dilaksanakan di Posyandu Widuri II Slarang dibawah binaan UPT Puskesmas Kesugihan 2 dengan Bidan Desa Slarang Ari Kurniasih, Amd. Keb. Pelaksanaan kegiatan pengabdian kepada masyarakat pada hari Selasa, 19 Februari 2019 pada jam 08.00 - 12.00 WIB. Dalam kegiatan ini dihadiri oleh 16 peserta yaitu ibu dan balita usia 3-5 tahun. Kegiatan yang dilakukan selama pengabdian yaitu :

1. Melakukan screening/pemeriksaan gangguan sensomotorik dan postural balita dengan menggunakan instrument Denver II (DDST) dan cek postural dengan pendulum. Dari hasil screening pada 16 balita, didapatkan hasil semua balita normal, tidak ada balita yang mengalami gangguan sensomotorik dan postural.

2. Melakukan kegiatan penyuluhan pada orang tua balita. Sebelum penyuluhan, dilakukan pengisian kuesioner pre test tentang dampak negatif penggunaan gadget pada balita oleh orang tua secara langsung. Dalam kegiatan pre test ini, diperoleh nilai rata-rata dari hasil pengisian kuesioner oleh ibu balita adalah 5,7. Setelah selesai pre tes, kegiatan berikutnya adalah melakukan pendidikan kesehatan / penyuluhan pada tiap orang tua balita tentang hasil screening, dampak penggunaan gadget, serta terapi dan latihan untuk mengurangi gangguan sensomotorik dan postural balita. Pendidikan kesehatan dilakukan kepada seluruh ibu balita sebanyak 16 orang. Dilakukan secara bergantian satu 
persatu sesuai urutan kehadiran dan dilakukan contoh terapi dan latihan pada balita secara langsung. Tahap akhir adalah melakukan pengisian kuesioner post tes pengetahuan orang tua. Hasil pengisian kuesioner post test didapatkan nilai rata-rata pengetahuan ibu balita tentang deteksi dini dan penanganan gangguan dampak negatif penggunaan gadget pada balita sebesar 8.1.

\section{2) Pembahasan}

Dari hasil screening gangguan sensomotorik dan postural oleh tim pengabdi, tidak ditemukan adanya gangguan tersebut pada seluruh balita yang diperiksa. Hal ini dimungkinkan dipengaruhi oleh frekuensi dan lamanya atau durasi waktu dalam penggunaan smartphone. Lama waktu yang digunakan balita untuk bermain smartphone (gadget) masih wajar yaitu sekitar kurang lebih 1-2 jam. Selain itu, dalam penggunaan smartphone (gadget) masih diselingi waktu istirahat. Penggunaan smartphone (gadget) hanya sebatas untuk melihat film kartun atau sekedar bermain game dengan pengawasan orangtua karena usia anak yang masih usia PAUD sehingga masih butuh pendampingan orang tua. Meskipun demikian, tetap harus diwaspadai dan diupayakan pencegahannya untuk mengurangi dampak negatif jika penggunaan gadget terlalu sering dan dalam jangka waktu yang panjang.

Hasil pengukuran pengetahuan orang tua balita melalui pre tes dan pos tes didapatkan adanya peningkatan nilai rata-rata post tes dibandingkan nilai pre tes. Melihat adanya peningkatan rata-rata nilai pre test ke post tes, maka hal ini dapat disimpulkan setelah dilakukan pengabdian, ada peningkatan pengetahuan orang tua terhadap dampak negatif dan penanganan dampak negatif penggunaan smartphone (gadget). Peningkatan pengetahuan ini kemungkinan dipengaruhi adanya penyuluhan yang dilakukan oleh tim pengabdi yang dilakukan pada saat setelah pre tes. Waktu jeda antara penyuluhan dan post test juga sangat dekat karena setelah penyuluhan selesai, langsung dilakukan penilaian post tes. Salah satu faktor untuk meningkatkan perilaku kesehatan yang baik adalah dengan melakukan pendidikan kesehatan. Notoatmodjo (2010) menyampaikan bahwa pendidikan kesehatan merupakan suatu kegiatan atau usaha yang digunakan untuk menyampaikan informasi kesehatan kepada individu, kelompok ataupun masyarakat, sehingga dapat memperoleh pengetahuan kesehatan yang lebih baik dan dapat berpengaruh 
terhadap perilakunya. Pengetahuan seseorang akan menjadi lebih baik jika mendapatkan informasi sebanyak-banyaknya. Informasi dapat diperoleh seseorang melalui adanya pendidikan kesehatan. Penyuluhan yang diberikan oleh tim pengabdi merupakan salah satu bentuk pendidikan kesehatan yang diberikan kepada orang tua balita secara langsung dengan memberikan informasi seputar penggunaan smartphone (gadget).

\section{KESIMPULAN}

Setelah dilakukan pemeriksaan pemakaian smartphone pada anak diwilayah slarang ini masih dalam kategori normal atau tidak berlebihan. Dari pemakaian smartphone (gadget) ini juga tidak ditemukaannya anak yang mengalami gangguan sensomotorik dan postural. Selain itu, pada orang tua terjadi peningkatan pengetahuan tentang dampak negatif penggunaan smartphone (gadget).

\section{DAFTAR PUSTAKA}

Notoatmodjo, Soekidjo. 2010. Promosi Kesehatan: Teori dan Aplikasi. Jakarta, Rineka Cipta

Novi, 2015. Kebiasaan - Kebiasaan Buruk Sehari hari, Yogyakarta: Flash book

Sari,P dan mitsalia A, 2016. Pengaruh Penggunaan Gadget Terhadap Personal sosial Anak usia Pra Sekolah Di TK IT Al Mukmin. Jurnal Profesi 13 (2): 7377

Ismanto Y\& Onibala,F. 2015. Hubungan Penggunaan Gadget Dengan Tingkat Prestasi Siswa Di SMA Negeri Manado. E journal Keperawatan FK Unsrat Manado,3 (2) 